\title{
Investigation the Effects of Cadmium Chloride and Copper Sulfate on Germination and Seedling Growth of Agropyron elongatum
}

\author{
Morteza Saberi(Corresponding author) \& Alireza Shahriari \\ Faculty of Natural Resources, University of Zabol, Iran \\ Tel.: 98-091-5954-4760; Fax: 98-054-2223-2600 E-mail: m_saberi63@yahoo.com
}

Farajollah Tarnian

Graduated M.Sc. Student of Range Management, University of Tehran, Karaj-Iran

Received: July 7, 2011

Accepted: September 15, 2011

doi:10.5539/mas.v5n5p232

\begin{abstract}
Toleration of germination and embryonic growth stage to heavy elements is as a key of plant establishment under limited conditions. In this study effects of two heavy metals, cadmium and copper sulfate and their interplays were evaluated on germination and growth of A. elongatum. Therefore A. elongatum seeds after disinfectant, placed on watman paper and influenced by cadmium $\left(10,20\right.$ and $\left.30 \mathrm{mg} \mathrm{L}^{-1}\right)$ and copper sulfate $\left(10,20\right.$ and $\left.30 \mathrm{mg} \mathrm{L}^{-1}\right)$. Distilled water was used as control treatment. Each treatment had 4 replications and there were 25 seeds for each replication. Germination of seeds was evaluated everyday and growth index was determined by measuring of root length, shoot length, seedling length and seed vigurity index. Results indicated that there weren't significant differences among the treatment of germination percentage and speed but length of roots, length of shoots, length of seedling and vigurity index reduced significantly by application of these heavy metals. Root length reduced from $6.2 \mathrm{~cm}$ in the control to $2.4 \mathrm{~cm}$ at $30 \mathrm{mg} \mathrm{L}^{-1} \mathrm{Cd}$ solution but it reduced from $6.3 \mathrm{~cm}$ in the control to $4.1 \mathrm{~cm}$ at $30 \mathrm{mg} \mathrm{L}^{-1} \mathrm{Cu}$ solution. Shoot length was reduced from $9.2 \mathrm{~cm}$ in the control to $4.6 \mathrm{~cm}$ at $30 \mathrm{mg} \mathrm{L}^{-1} \mathrm{Cd}$ solution and reduced from $9.4 \mathrm{~cm}$ in control to $5.6 \mathrm{~cm}$ at $30 \mathrm{mg} / \mathrm{L} \mathrm{Cu}$ solution.
\end{abstract}

Keywords: Agropyron elongatum, Cadmium, Copper sulfate, Germination, Stress

\section{Introduction}

Presence of heavy elements in soil is one of the most important environmental stresses that can reduce growth reduction. Elements are in the crust of earth in various amounts naturally. Presence of heavy elements can cause different negative effects in plants such as growth reduction, reduction of chlorophyll contents and photosynthesis, limitation of enzymes activities, damage to biotic molecules included lipids, proteins and nucleic acids spatially DNA (Chaoui and Ferjani, 2005; Mishra et al., 2006). Cadmium is one of the toxic elements for organism. This element enters to environment mainly through industrial process and phosphorous fertilizers and then goes to the nutrient cycle. Cadmium in polluted soils in the form of free ions or ions can be solve easily (Hardiman and Jakoby, 1984). Different studies on different plants show that cadmium can absorb by roots easily (Blinda et al., 1997). This element is toxic for plant intervenes in many of cell actions by formation of complicated complex with lateral groups of organic compositions such as proteins and as a result prevents of necessary activities of cell. Also it stimulates genetic and biochemical changes that are general reaction of plant against cadmium stress (Metwally et al., 2003). Cadmium has special importance among heavy elements because it absorbs easily by root system of plant and its toxicity for plant is 2-20 times more than other heavy elements. For most plants if cadmium concentrations are 20-30 mg gr ${ }^{-1} \mathrm{Cu}$ in dry matter it can cause poisoning of plant that can stop root growth, reduce tillering in beans. Dark green color is one of the significant symptoms of this element (Marschner, 1958). Peralta et al. (2000) showed that Medicago sativa plant can growth in some heavy component of soil. They investigated effect of elements included Manganese, Nichol, Copper, Crum and Cadmium on growth and survival of Medicago plant. They concluded that seed germination and plants growth affected by chromium and Cadmium at $10 \mathrm{ppm}$ concentration which was significant but Manganese hadn't effect on them. Jeliazkova et al. (2003) investigated effect of heavy metals component $(\mathrm{Cu}$ and $\mathrm{Mn}),(\mathrm{Cu}$ and $\mathrm{Pb}),(\mathrm{Cd}$ and $\mathrm{Mn}),(\mathrm{Cd}$ and $\mathrm{Pb})$ and $(\mathrm{Cu}$ and $\mathrm{Cd})$ on growth and germination of Pimpinella anisum, Carum carvi and Foeniculum vulgare species. Results showed that primary growth of root was affected by heavy elements more than germination. Mahmood et al. (2005) investigated effects of different levels of copper and zinc on germination and growth of Zea mays embryo. Any of treatments wasn't affected on seed germination while primary growth was confined. They indicated that toxicity 
symptoms in embryos was increased in presence of both elements $\left(\mathrm{CusO}_{4}\right.$ and $\left.\mathrm{ZnsO}_{4}\right)$ and amount of toxicity related to $\mathrm{Znso}_{4}$ was more than $\mathrm{CusO}_{4}$. Shaukat et al. (1999) also investigated effect of cadimium, chromium and lead on seed germination, early seedling growth and phenol contents of parkinsonia aculeate and pennisetum americanum. Their results indicated that final germination percentage was greatly reduced by cadmium, chlorine and lead salts in both the test species at the concentration of $50 \mathrm{ppm}$ or more.

A. elongatum is one of the most important species in recovering and developing of rangeland which is especially tolerant to saline soils. It is adapted to irrigated or subirrigated saline soils and to imperfectly-drained, alkali soils. It prefers soils with a high water table. Germination and seedling growth are the key events for the establishment of plants under any prevailing environment. This research was conducted to study effects of cadmium and copper sulfate on germination and seedling growth of $A$. elongatum seeds.

\section{Materials and methods}

The seeds of this plant were collected from Taleghan rangelands. The experiment was undertaken for one month from 2009/6/25 to 2009/7/25, at the faculty of natural resources, Tehran University. At first large and healthy seeds was separated from wrinkled and infertile seeds and disinfected by hypochloride (5\%) and then washed with distilled water 3 times. All devices such as petery dishes and filter papers were sterilized in autoclave. This research was carried out using completely randomized design in 4 replications. After providing petery dishes, 25 seeds were placed at each petery dishes and different treatment were prepared included: distilled water as control treatment, $\mathrm{CusO}_{4}$ and $\mathrm{Cdcl}_{5}$ as $\mathrm{Cu}$ and $\mathrm{Cd}$ elements. And these concentrations were prepared according to $\mathrm{mg} \mathrm{L}^{-1}$ : $(10,20$ and 30$) \mathrm{cu}$ and $(10,20$ and 30$) \mathrm{cd}$. Then they were placed at growth cabin with $23^{0 \mathrm{c}}$ temperature and after seeds plantation, numbers of germinated seeds were numbered daily at each experiment unit to determine germination speed. Germination percentage and speed, length of roots, length of shoots, and length of plant and vigority index were measured after proper growth of embryos ( 8 days). Germination percentage, germination speed (Maguirw, 1962), vigority index (Balestrasse et al., 2001) and plant length was calculated based on the following relations:

(1) germination percentage ${ }_{G P}=\frac{\sum G}{N} \times 100$

GP: germination percentage, G: number of germinated seeds, N: number of seeds

(2) germination speed $G R=\sum_{i=1}^{n} \frac{S_{i}}{D_{i}}$

$\mathrm{S}_{\mathrm{i}}$ : number of germinated seed at each counting, $\mathrm{D}_{\mathrm{i}}$ : number of day until $\mathrm{n}$ counting, $\mathrm{n}$ : numbers of counting

(3) vigority index $=$ total germination percentage $\times$ plant length

(4) plant length $=$ root length + shoot length

Obtained data was analyzed using SPSS software. Significant differences related to treatment were compared using Duncan test after performing variance analysis.

\section{Results}

Results of variance analysis the effects of cadmium chloride and copper sulfate on A. elongatum on properties included germination percentage, germination speed, length of root, length of shoot, length of embryo and vigority index were reported in table land 2 . There were significant differences in some properties which include length of root, length of shoot, length of embryo and vigority index under the $\mathrm{Cd}$ and $\mathrm{Cu}$ stress. Results also indicated that there was significant differences among germination percentage under $\mathrm{Cu}$ stress.

Results showed that germination percentage of $A$. elongatum was reduced when $\mathrm{Cd}$ and $\mathrm{CusO}_{4}$ concentrations increased. Maximum of germination percentage (95\%) was related to control treatment and minimum amount of it $(85.5 \%)$ was related to $\mathrm{Cu}\left(30 \mathrm{mg} \mathrm{L}^{-1}\right)$ (Figure 1).

Comparing of germination speed means were reported at Figure 2. There weren't significant differences among different levels of cadmium and copper sulfate with control treatment.

Length of root was reduced when cadmium and copper sulfate concentrations increased. Mean comparison showed that maximum of root length $(6.4 \mathrm{~cm})$ was related to control treatment and minimum of it $(2.5 \mathrm{~cm})$ was related to Cd treatment (30 $\left.\mathrm{m} \mathrm{L}^{-1}\right)$ (Figure 3).

Duncan's test determined 3 groups on shoot length. Minimum of shoot length $(4.7 \mathrm{~cm})$ was related to $\mathrm{Cd}$ and maximum of it $(9.3 \mathrm{~cm})$ was related to control treatment (Figure 4$)$. 
Length of plant was reduced with accelerating of cadmium and copper sulfate concentrations. Maximum of plant length $(15.9 \mathrm{~cm})$ was related to control treatment and minimum of it $(7.1 \mathrm{~cm})$ was related $\mathrm{Cd}$ treatment $\left(30 \mathrm{mg} \mathrm{L}^{-1}\right)$ (Figure 5).

Vigority index was affected by $\mathrm{Cd}$ and $\mathrm{Cuso} 4$ and was reduced when concentrations of these two elements was increased. Maximum of vigority index was related to control treatment and minimum of it was related to $30 \mathrm{mg} \mathrm{L}^{-1}$ treatment of each two heavy elements (Figure 6).

\section{Discussion}

Toleration of germination and embryonic growth stage to heavy elements is as a key of plant establishment under limited conditions. Reaction to environmental stress in plants is an undeniable and complicated phenomenon. Obtained results from this research showed that various concentrations of cadmium and copper sulfate can reduce germination and growth of A. elongatum embryos and stop growth so that high concentrations of cadmium treatment could stop growth and even cause death of roots. These results are coincidence to the results of Dražić et al. (2006) that reported Cd decreased root and shoot of alfalfa seedling and to the results of Li et al. (2005). Growth reduction under $\mathrm{Cd}$ toxicity conditions was also observed for several species tested, including Cucumus sativus (Abu-Muriefah, 2008), Lemna polyrrhiza (John et al., 2008) and Glycyrrhiza uralensis (Zheng et al., 2010). However $\mathrm{Cd}$ decreased the germination speed and percentage but it doesn't have any significant effect on them. Decrease of germination percentage at 20 and $30 \mathrm{mg} \mathrm{L}^{-1} \mathrm{Cd}$ level was much more than that of $10 \mathrm{mg} \mathrm{L}^{-1} \mathrm{Cd}$ level. These results are contradictory to the results of Jeliazkova and Craker (2003) that reported Cd at $6 \mathrm{mg} \mathrm{L}^{-1}$ stimulated seed germination and root growth of caraway by approximately 20 percent as compared with the control. These differences may be because of different sensibility of plant species to toxic levels of heavy metals. Malekzadeh et al. (2007) reported that Cd decreased root length of Zea mays but it doesn't have any effect on shoot length of Zea mays. Cd had significant effect on both shoot and root length which this is Contradictory to the result of shoot length of Zea mays reported by Malekzadeh et al. (2007). Comparing of different mean gradient of studied properties showed that various concentrations of $\mathrm{Cd}$ have maximum negative effect on length of embryos. Increasing of heavy element in root environment can cause reduction of absorption of water and nutrients, reduction of water transpiration and disturbance in water balance, prevention of enzymes activities, reduction of cell metabolism, reduction of photosynthesis, evaporation and transpiration, nitrogen and phosphor shortage and stopping of growth, accelerating of maturity and even death of plant (Peralta et al., 2000; Cheng and Huang, 2006). Also absorption of high amount of $\mathrm{Cd}$ in plant can reduce and stop root growth and cause corky structure and reduce electrical conductivity of water in roots, reduction of necessary nutrient absorption such as $\mathrm{K}, \mathrm{Mg}$ and $\mathrm{Fe}$ (Gussarsson et al., 1996).

Results also indicated that $\mathrm{Cu}$ doesn't have significant effect on germination speed but it had significant effect on germination percentage. High concentration of copper sulfate has maximum effect on germination percentage. Mahmood et al. (2007) found that among the metals (include: $\mathrm{Zn}, \mathrm{Pb}, \mathrm{Mg}$ and $\mathrm{Na}$ ), $\mathrm{Cu}$ had the most adverse effects on seed germination of Hordeum vulgare L., Oryza sativa L. and Triticum aestivum L. Comparing to control, germination percentage doesn't have significant differences at $10 \mathrm{mg} \mathrm{L}^{-1}$ but it decreased significantly at $20 \mathrm{mg} \mathrm{L}^{-1}$ $\mathrm{Cu}$ level. Street et al. (2007) reported that Copper at $1 \mathrm{mg} \mathrm{L}^{-1}$ significantly $(\mathrm{p}<0.05)$ reduced the percentage germination of Eucomis autumnalis. $\mathrm{Cu}$ also reduced the root and shoot length of seedlings similar to what reported by Street et al. (2007) about decreasing effect of $\mathrm{Cu}$ on root length of Bowiea volubilis, Eucomis autumnalis and Merwilla natalensis and by Chaffai et al. (2006). Adverse effects of $\mathrm{Cu}$ on roots are related to severe reduction in the elongation growth of the longest root as well as root plasma membrane permeability of the seedlings (Nriagu and Pacyna, 1988; McBride, 2001; Chaffai et al., 2006). Hall and Williams (2003) reported that the toxic effects of $\mathrm{Cu}$ often affected mitotic activity and cell division of roots.

\section{Conclusion}

In generally results of this research showed that different levels of copper sulfate and cadmium can cause negative effects on different growth aspects of $A$. elongatum and these effects are clearly visible. These results can important to understanding of cadmium and copper sulfate mechanisms and founding solutions to prevent of infiltration of these elements to valuable rangeland plants.

\section{References}

Abu-Muriefah, S. S. (2008). Growth parameters and elemental status of cucumber (Cucumus sativus) seedlings in response to cadmium accumulation. International Journal of Agriculture and Biology, 10, 261-266, ISSN Online: $1814-9596$

07-408/AWB/2008/10-3-261-266,

http://www.fspublishers.org/ijab/past-issues/IJABVOL_10_NO_3/4.pdf 
Balestrasse, K.B., Gardey, L., Gallego, S.M., and Tomaro, M.L. (2001). Response of antioxidant defense system in soybean nodules and roots subjected to cadmium stress. Australian Journal Plant Physiology, 28, 497-504, DOI:org/10.1071/PP00158, http://dx.doi.org/10.1071/PP00158

Blinda, A., Koch, B., Ramanjulu, S., and Dietz, K.J. (1997). De novo synthesis and accumulation of apoplast proteins in leaves of heavy metal exposed barley seedlings, Journal of Plant cell Environment, 20, 969-981, DOI:10.1111/j.1365-3040.1997.tb00674.x,

http://onlinelibrary.wiley.com/doi/10.1111/j.1365-3040.1997.tb00674.x/pdf

Chaffai, R., Tekitek, A., and El Ferjani, E. (2006). A comparative study on the organic acid content and exudation in maize (Zea mays L.) seedlings under conditions of copper and cadmium stress. Asian Journal of Plant Science, 5, 598-606, ISSN 1682-3974 Volume: 5; Issue: 4; Start page: 598; Date: 2006, DOI:10.3923/ajps.2006.598.606, http://scialert.net/abstract/?doi=ajps.2006.598.606

Chaoui, A., and Ferjani, E.E.I. (2005). Effects of cadmium and copper on antioxidant capacities, lignification and auxin degradation in leaves of Pea (Pisium sativum L) seedlings. Journal of Comptes Rendus Biologies, 328, 23-31, DOI:10.1016/j.crvi.2004.10.001, http://www.sciencedirect.com/science/article/pii/S1631069104002355

Cheng, S.F., and Huang CY, (2006). Influence of cadmium on growth of root vegetable and accumulation of cadmium in the edible root. International Journal of Applied Science Engineering, 3, 243-252, ISSN: 1727-2394, http://www.cyut.edu.tw/ ijase/2006/4-3(010-008-3).pdf

Dražić, G., Mihailović, N., and Lojić, M. (2006). Cadmium accumulation in Medicago sativa seedlings treated with salicylic acid. Biological plantrum, 50, 239-244, DOI:10.1007/s10535-006-0013-5, $\mathrm{http}: / / \mathrm{www}$.ingentaconnect.com/content/klu/biop/2006/00000050/00000002/00000013

Gussarsson, M., Asp, H., Adalsteinsson, S., and Jensén, P. (1996). Enhancement of cadmium effects on growth and nutrient composition of birch (Betula pendula) by buthionine sulphoximine (BSO), Journal of Exp. Bot, 47, 211-215, DOI:10.1093/jxb/47.2.211, http://jxb.oxfordjournals.org/content/47/2/211.full.pdf

Hall, J.L., and Williams, L.E. (2003). Transition metal transporters in plants. Journal of Experimental Botany, 54, 2601-2613, DOI:10.1093/jxb/erg303, http://jxb.oxfordjournals.org/content/54/393/2601.full.pdf + html

Hardiman, R.T., and Jacoby, B. (1984). Absorption and translocation of Cd in bush bean (Phaseolus vulgaris). Journal of Physiologia Plantarum, 61, 670-674, DOI: 10.1111/j.1399-3054.1984.tb05189.x, http://onlinelibrary.wiley.com/doi/10.1111/j.13993054.1984.tb05189.x/abstract;jsessionid=2DE4721C8750D694 7C6B1E4A232148F2.d01t03

Jeliazkova, E.A., and Craker, L.E. (2003). Seed germination of some medicinal and aromatic plants in heavy metal environment. Journal of Herbs, Spices \& Medicinal Plants, 10, 105-112, DOI:10.1300/J044v10n02_12, http://www.tandfonline.com/doi/abs/10.1300/J044v10n02_12\#preview

Jeliazkova, E.A., Craker, L.E., and Xing, B. (2003). Seed germination of anise, caraway, and fennel in heavy metal contaminated solutions. Journal of Herbs, Spices and Medicinal Plants, 10, 83-93, DOI:10.1300/J044v10n03_09, http://www.tandfonline.com/doi/abs/10.1300/J044v10n03_09\#preview

John, R., Ahmad, P., Gadgil, K., and Sharma, S. (2008). Effect of cadmium and lead on growth, biochemical parameters and uptake in Lemna polyrrhiza L. Plant, Soil and Environment, 54, 262-270, http://www.agriculturejournals.cz/publicFiles/01591.pdf

Li, W., Khan, M.A., Yamaguchi, Sh., and Kamiy, Y. (2005). Effects of heavy metals on seed germination and early seedling growth of Arabidopsis thaliana. Plant Growth Regulation, 46, 45-50, DOI: 10.1007/s10725-005-6324-2, http://www.springerlink.com/content/v68g474443167213/

Maguirw, I.D. (1962). Speed of germination arid in selection and evaluation for seedling emergence and vigor. Journal of Crops Science, 2, 176-177.

Mahmood, S., Hussain, A., Saeed, Z., and Athar, M. (2005). Germination and seedling growth of corn (Zea mays L.) under varying levels of copper and zinc. International Journal Environmental Science and Technology, 2, 269-274, http://www.bioline.org.br/abstract?id=st05037, http://www.ceers.org/ijest/issues/full/v2/n3/203012.pdf

Mahmood, T., Islam, K.R., and Muhammad, S. (2007). Toxic effect of heavy metals on early growth and torelance of cereal crops. Pakistan Journal of Botany, 39, 451-462, DOI:0556-3321, http://hero.epa.gov/index.cfm?action=search.view\&reference_id $=497395$ 
Malekzadeh, P., Khara, J., Farshian, S., Jamal-Abad, A.K., and Rahmatzadeh, S. (2007). Cadmium toxicity in maize seedlings: Changes in antioxidant enzyme activities and root growth. Pakistan Journal of Biological Science, 10, 127-131, DOI:10.3923/pjbs.2007.127.131, http://scialert.net/abstract/?doi=pjbs.2007.127.131

Marschner, H. (1958). Mineral nutrition of higher plants. 2nd. Ed., Academic Press. New York, NY, 674 p. DOI:10.1111/j.1365-3040.1988.tb01130.x

McBride, M.B. (2001). Cupric ion activity in peat soil as a toxicity indicator for maize. Journal of Environmental Quality, 30: 78-84. DOI:10.2134/jeq2001.30178x, http:/www.ncbi.nlm.nih.gov/pubmed/11215669

Metwally, A., Finkemeier, I., Georgi, M. and Dietz, K.J. (2003). Salicylic acid alleviates the cadmium toxicity in barley seedlings. Journal of Plant Physiology, 132, 272-281, DOI:10.1104/pp.102.018457, http://www.plantphysiol.org/content/132/1/272.full.pdf + html

Mishra, S., Srivastava, S., Tripathi, P.D., Govindarajan, R., Kuriakose, S.V., and Prasad, M.N.V. (2006). Phytochelatin synthesis and response of antioxidants during cadmium stress in Baccopa monnieri L. Journal of Plant Physiology and Biochemistry, 44, 25-37, DOI.org/10.1016/j.plaphy.2006.01.007, http://www.isch.edu.cu/areas/fitorem/Materiales_Fitored/Grupo $\% 20$ Fitoplant/Bibliografia $\% 20$ Fitorremediaci $\% \mathrm{~F}$ $3 \mathrm{n} /$ Fitorremediacion $\% 20 \mathrm{IV} /$ Bibliografia $\% 20$ Ecuador/fitoquelatinas $\% 20 \mathrm{y} \% 20$ antioxidantes $\% 20$ estres $\% 20 \mathrm{Cd}$.pdf

Nriagu, J.O., and Pacyna, J.M. (1988). Quantitative assessment of worldwide contamination of air, water and soil by trace-metals. Nature, 333, 134-139, doi:10.1139/a01-012, http://www.ncbi.nlm.nih.gov/pubmed/3285219

Peralta, J.R., Gardea-torresdey, J.L., Tiemann, K.J., Gómez, E., Arteaga, S., Rascon, E., and Parsons, J.G. (2000). Study of the effects of heavy metals on seed germination and plant growth on alfalfa plant (Medicago sativa) grown in soild media, Proceedings of the 2000 Conference on Hazardous Wast Research, pp: 135-140., http://www.engg.ksu.edu/hsrc/00Proceed/gardea1.pdf

Shaukat, S.S., Mushtaq, M., and Siddiqui, Z.S. (1999). Effect of cadmium, chromium and lead on seed germination, early seedling growth and phenolic contents of Parkinsonia aculeata L. and Pennisetum americanum (L.) Schumann. Pakistan Journal of Biological Science, 2, 1307-1313, DOI:10.3923/pjbs.1999.1307.1313, http://docsdrive.com/pdfs/ansinet/pjbs/1999/1307-1313.pdf

Street, R.A., Kulkarni, M.G., Stirk, W.A., Southway, C., and Van Staden, J. (2007). Toxicity of metal elements on germination and seedling growth of widely used medicinal plants belonging to hyacinthaceae. Bull Environ Contam Toxicol, 79, 371-376, DOI:org/10.1007/s00128-007-9237-0, http://www.springerlink.com/content/9u48q814422t7217/

Zheng, G., Lv, H.P., Gao, S. and Wang, S.R. (2010). Effects of cadmium on growth and antioxidant responses in Glycyrrhiza uralensis seedlings. Plant, Soil and Environment, 56, 508-515, DOI: 1214-1178 v.56(11) p.508-515, http://journals.uzpi.cz/publicFiles/30033.pdf 
Table 1. variance analysis of effect of cadmium on studied properties of $A$. elongatum

\begin{tabular}{ccccc}
\hline properties & ss & df & ms & $\mathrm{f}$ \\
\hline Germination percentage & 16 & 3 & 5.3 & $0.5^{\text {ns }}$ \\
Germination speed & 11.1 & 3 & 3.7 & $15.6^{\text {ns }}$ \\
Root length & 32.6 & 3 & 10.8 & $25.3^{* *}$ \\
Shoot length & 52.5 & 3 & 17.5 & $63.2^{* *}$ \\
Plant length & 167.1 & 3 & 55.7 & $80.6^{* *}$ \\
Seed vigority & 1564913 & 3 & 251637 & $70.4^{* *}$ \\
\hline
\end{tabular}

**Significant difference between treatments at $1 \%$ levels, ns: non significant

Table 2. variance analysis of effect of copper sulfate on studied properties of $A$. elongatum

\begin{tabular}{ccccc}
\hline properties & ss & $\mathrm{df}$ & $\mathrm{ms}$ & $\mathrm{f}$ \\
\hline Germination percentage & 229.6 & 3 & 76.5 & $10.8^{* *}$ \\
Germination speed & 8.6 & 3 & 2.8 & $2.1^{\mathrm{ns}}$ \\
Root length & 12.1 & 3 & 4 & $25.4^{* *}$ \\
Shoot length & 36.6 & 3 & 12.2 & $63.2^{* *}$ \\
Plant length & 77.3 & 3 & 25.7 & $51^{* *}$ \\
Seed vigority & 954669 & 3 & 318283 & $59.7^{* *}$ \\
\hline
\end{tabular}

**Significant difference between treatments at $1 \%$ levels, ns: non significant 


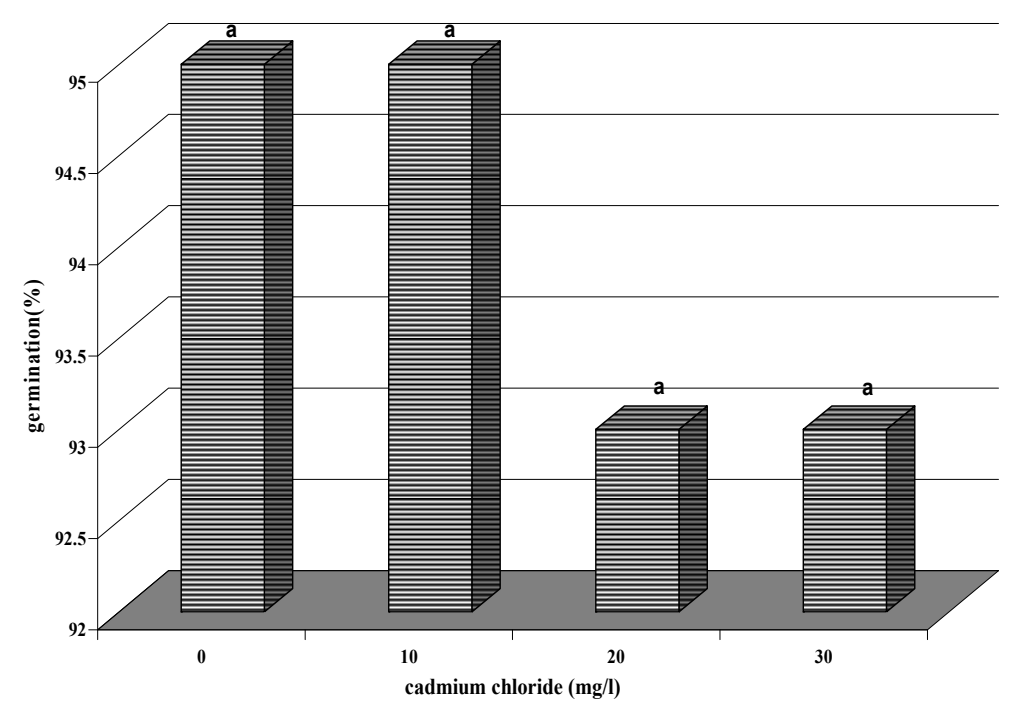

(a)

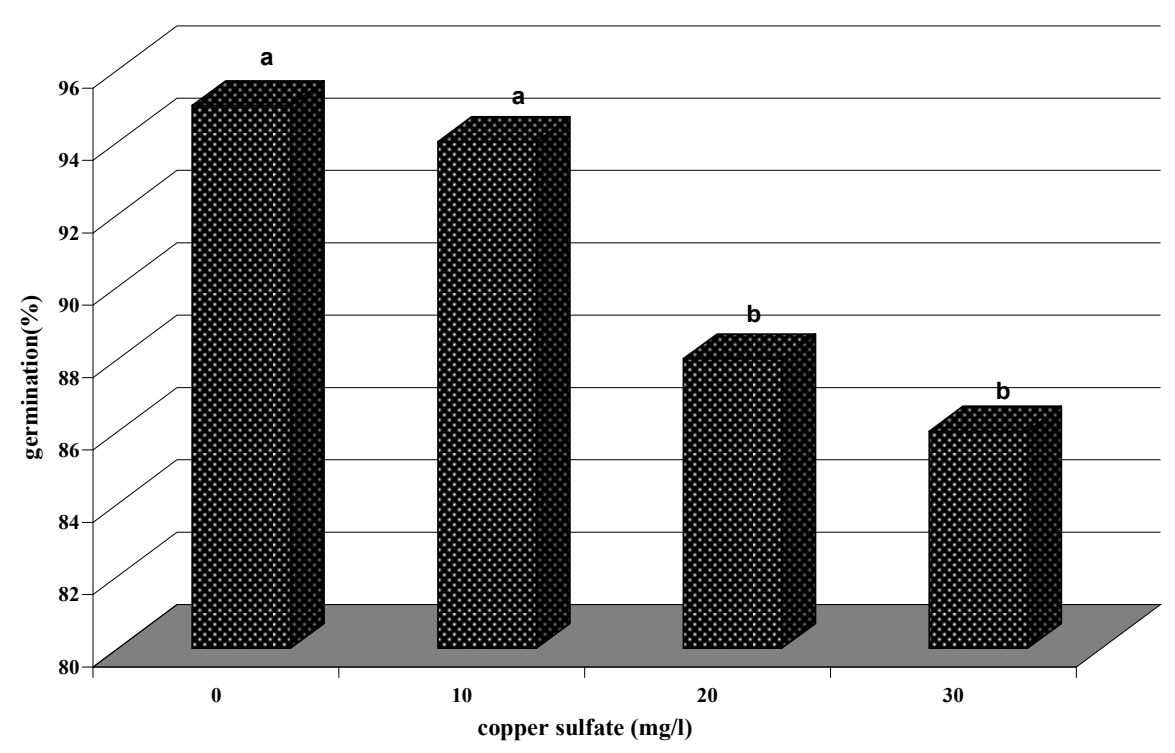

(b)

Figure 1. comparing effects of cadmium chloride (a) and copper sulfate (b) on germination percentage of $A$. elongatum 


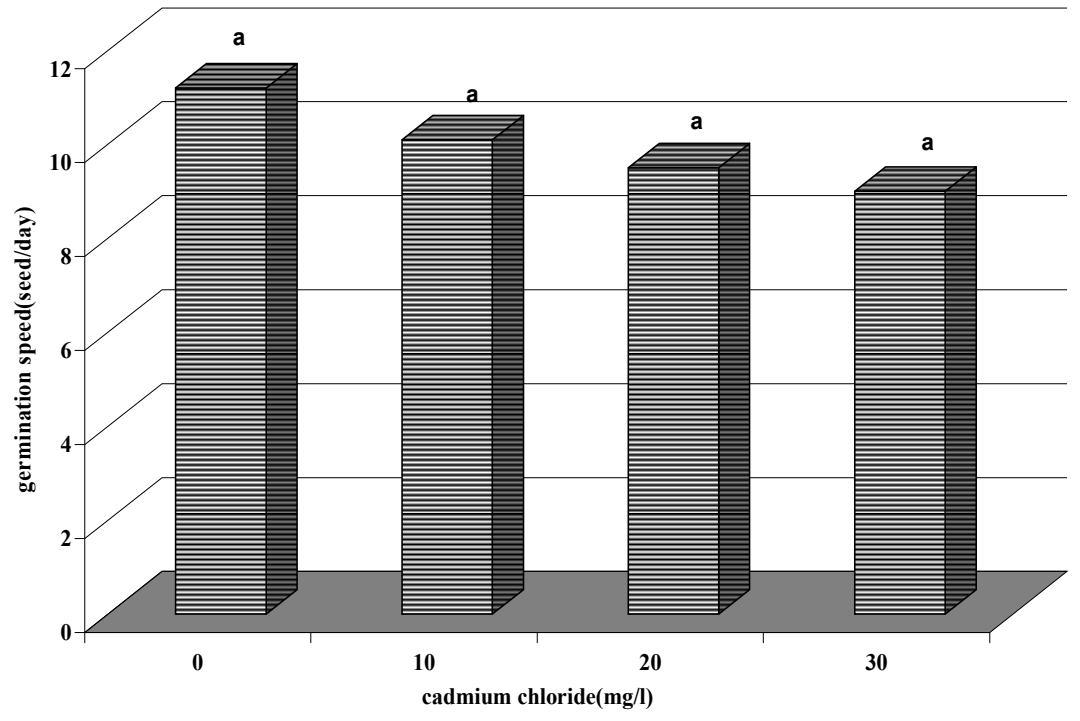

(a)

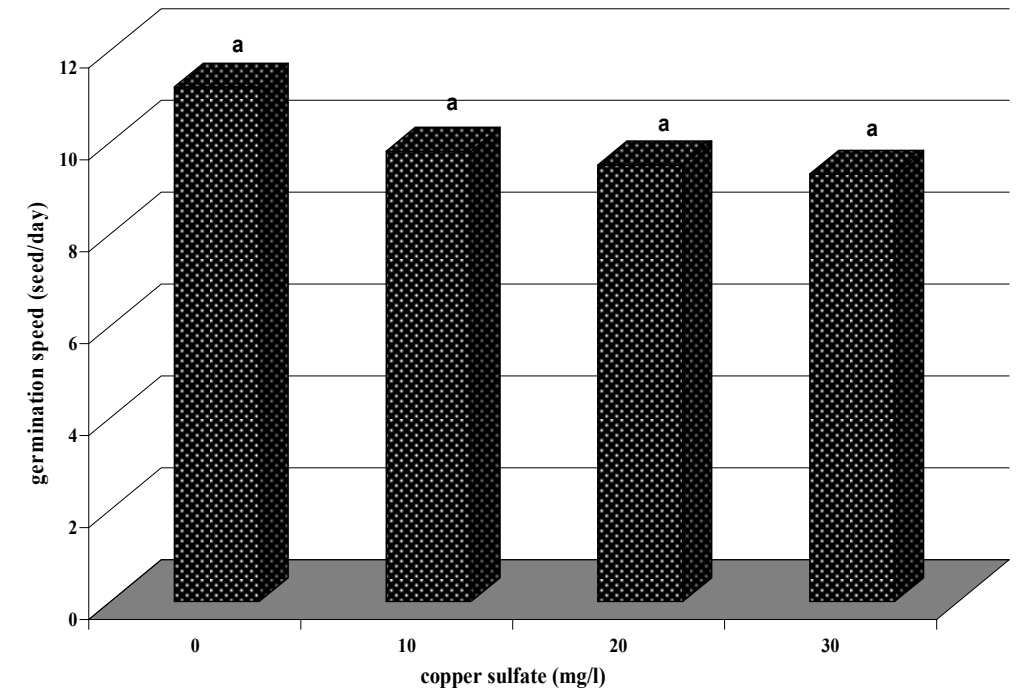

(b)

Figure 2. comparing effects of cadmium chloride (a) and copper sulfate (b) on germination speed of A. elongatum 


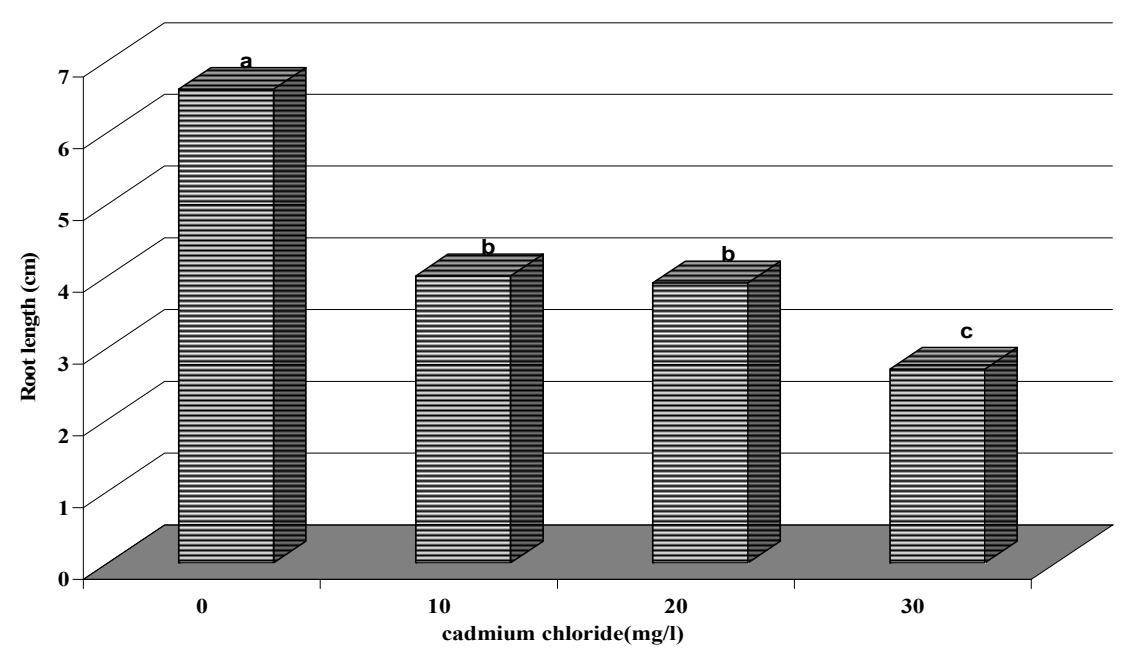

(a)

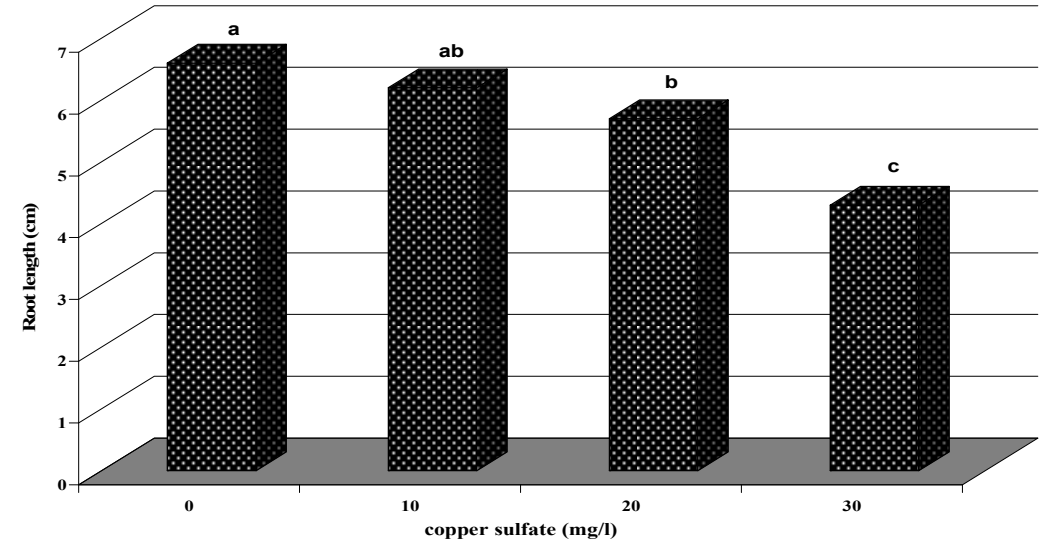

(b)

Figure 3. comparing effects of cadmium chloride (a) and copper sulfate (b) on Root length of A. elongatum 


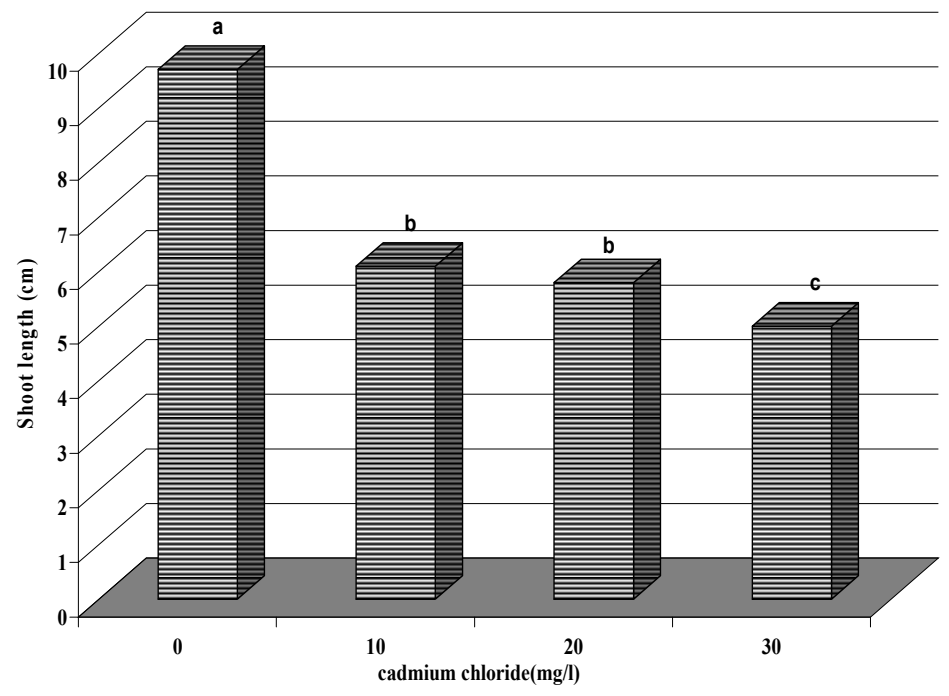

(a)

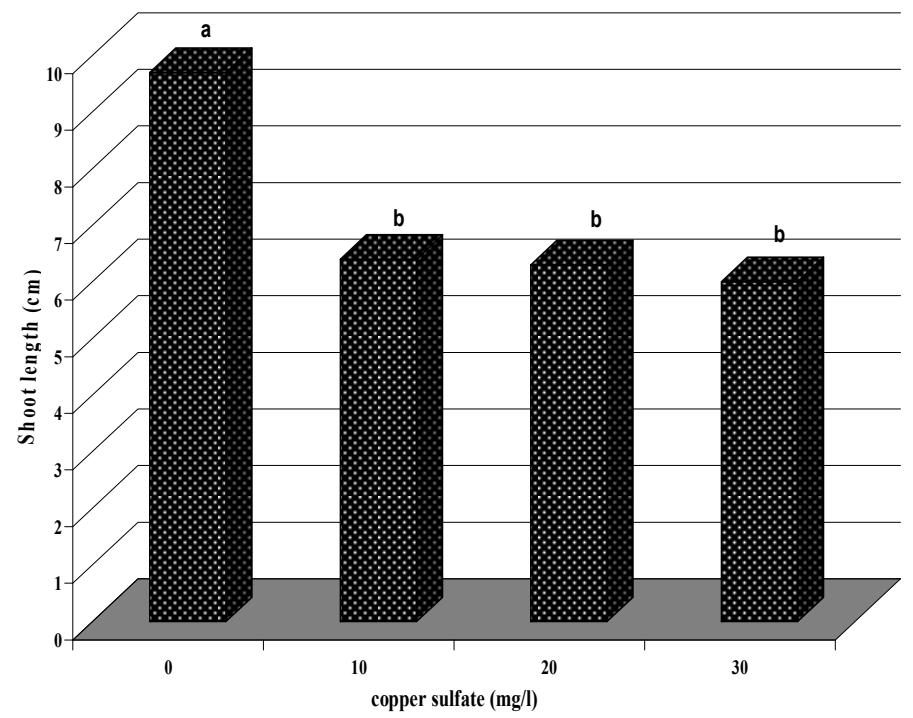

(b)

Figure 4. comparing effects of cadmium chloride (a) and copper sulfate (b) on Shoot length of $A$. elongatum 


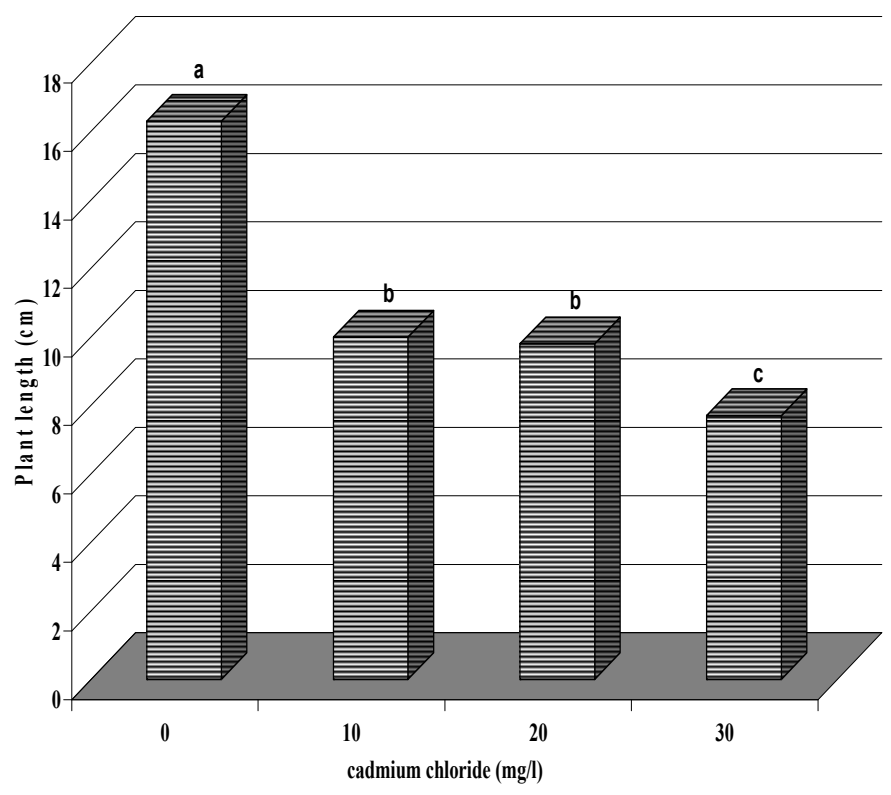

(a)

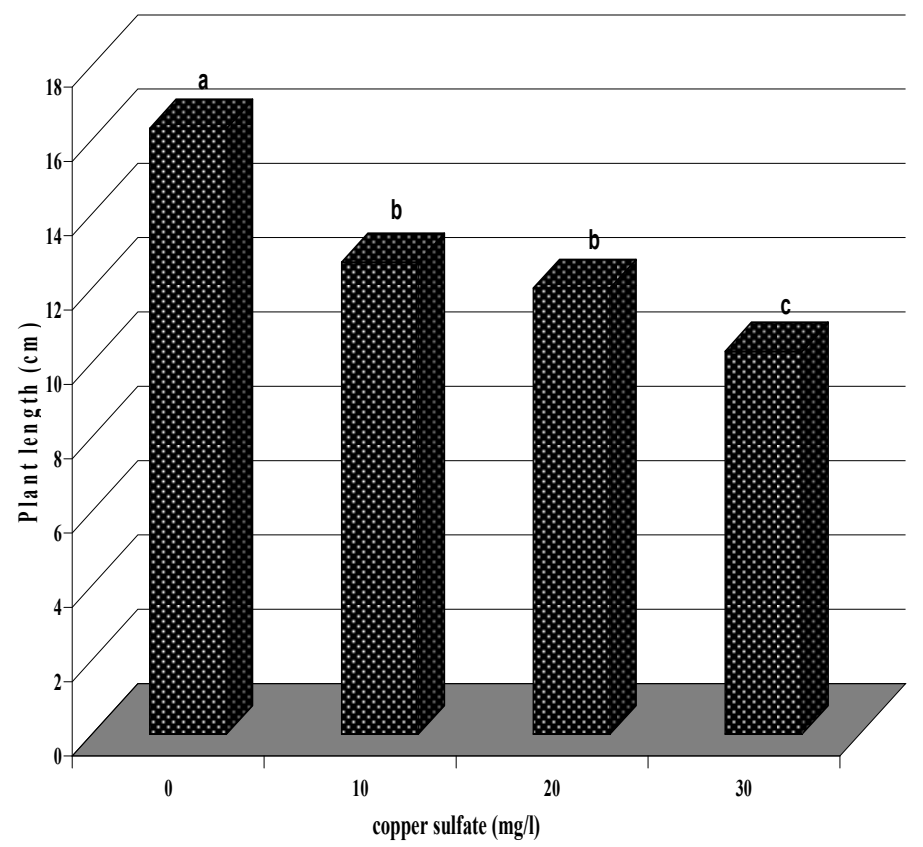

(b)

Figure 5. comparing effects of cadmium chloride (a) and copper sulfate (b) on Plant length of A. elongatum 


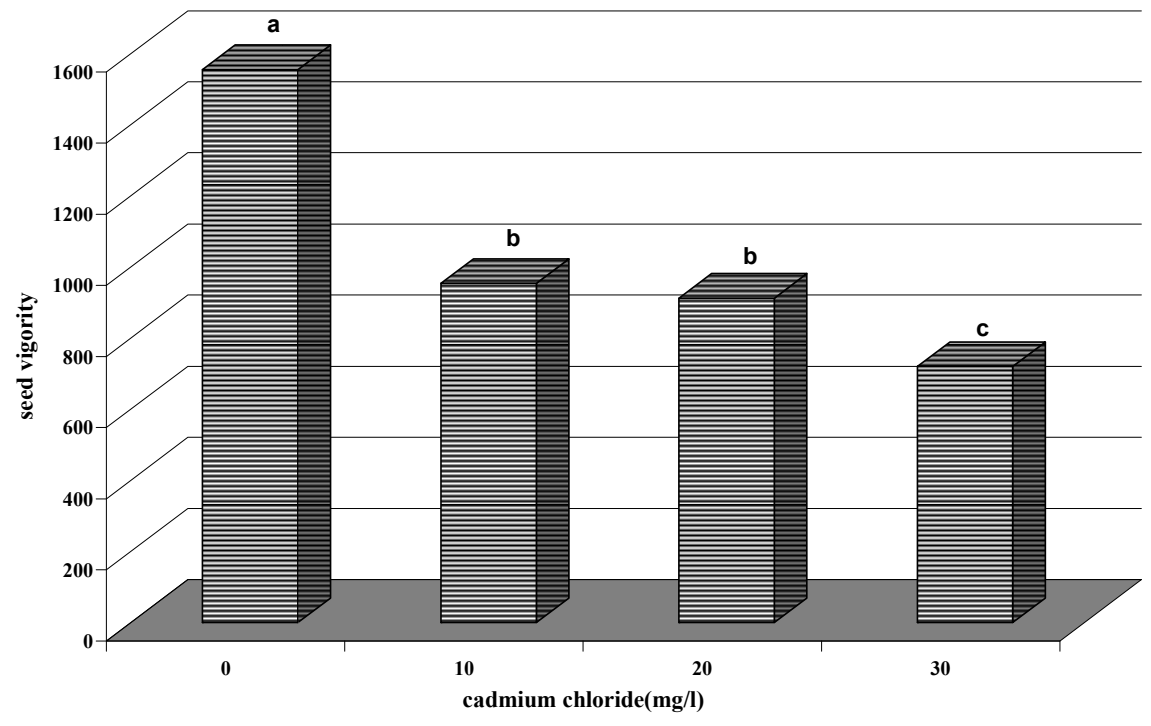

(a)

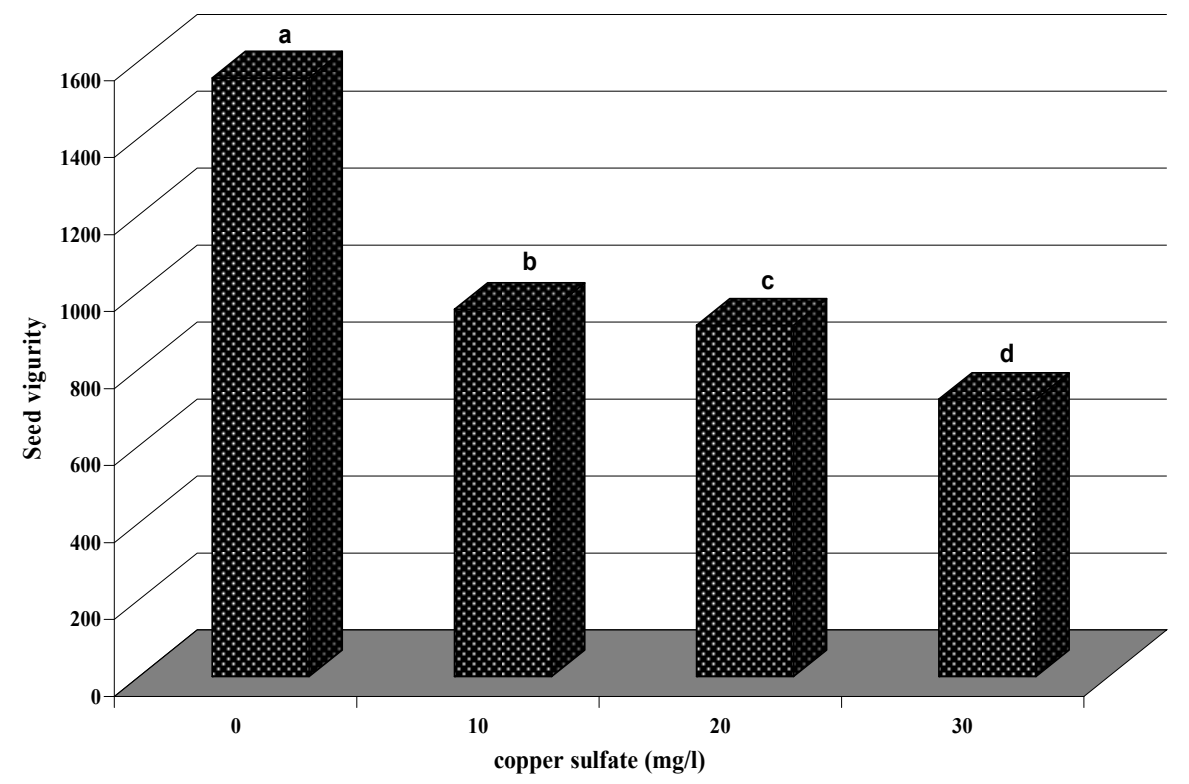

(b)

Figure 6. comparing effects of cadmium chloride (a) and copper sulfate (b) on Seed vigority of A. elongatum 